XVII. On the apparent Identity of Sphinx Ephemeræformis of Haworth, with Psyche plumifera of Ochsenheimer. By J.F.Stephens, F.L.S.Z.S., V.-Pres. Ent. Soc., \&c.

[Read June 2, 1834.]

PLATE X. Fig. 1.

WhAт is Sphinx Ephemeraformis of Haworth ?-is an inquiry which has been repeatedly, but fruitlessly, made during the last thirty years; an inquiry rendered more interesting from the very peculiar characters which have been assigned to the insect in question,characters* totally at variance with those which distinguish any insect of the group in which it has been placed. One of our colleagues has published an essay, containing some ingenious and singular theoretical views, in order to investigate the identity, and the place in nature, of Sphinx Vespiformis of Linnæus (Ageria asiliformis of English writers); but I shall content myself with a short paper only, unshackled by theory, with a view to identify the insect now under consideration, and to assign it to its proper location in the system.

This insect, rendered thus conspicuous from having been described in a slightly mutilated state, has by chance fallen into my possession, having recently obtained it at an auction of some of Mr. Donovan's insects, in the sale catalogue of which it was announced as an "undescribed Cossus ligniperda"'

By the assistance of my friend Mr. Westwood, I am enabled to present the Society with a figure of this unknown (for so it may justly be termed) insect, which, upon the most cursory inspection, proved to be no Sphinx, nor even to belong to that section of which Sphinx is the type, but to the singular group known by the name of "Sacktrïgers" + by the Germans, and considered by some writers as belonging to another order of insects + : in fact, it appears to be a Psyche of Ochsenheimer-(Ps. plumifera)-so far as can be ascertained by the remains of the unique specimen described in Lepidoptera Britannica, p. 72, by the following short characters:

"Antennis pectinatis, apice setaceis, alis fenestratis venis fuscolutescentibus, abdomine ezonato.

“ Obs. Magnitudo et statura Ephemeræ minoris."

" "Antennis pectinatis, apice setaceis."

† Tinea, Canephora, Hübner.

$\$$ Mr. Newman, in the essay above referred to, places them with the Trichoplira; Scopoli places two species with Phryganca; and Poda one with Tenthredo. 
An examination of the accompanying figure will at onse show the correctness of the above concise description, drawn up, as my lamented friend Haworth assured me, at the period of Drury's sale, at which the insect was purchased by Donovan; since when it has been hidden from view, till the mutability of human possessions once more brought it into light: but, at the same time, it is manifest that its location is not amongst the AEgeriida (see $E g$. formiciformis, the insect next to which it is placed in Lepidoptera Britannica, p. 72.), the structure of the antennæ, neuration of the wings, \&c. being dissimilar; neither has it any alliance with Zeuzera, to which genus it would appear Donovan assigns it, the sole resemblance thereto arising from the apparent simplicity of the tip of the pectinated antennæ; the neuration of the wings in Zeuzera and its congeners being totally unlike, the discoidal areolet being singularly intersected with nervures, whereas, in the insect now under examination that areolet is simple; the only resemblance being that the first posterior nervure is bifid in both insects.

From the mutilated state of the insect it would be mere waste of time to attempt an amended description of the specimen; I shall therefore merely add, that upon examining it, with reference to its genus, by inspecting the antennæ, it was palpable that the latter had been injured, and that the pectinations had been partly destroyed; but I am not positive whether or no the extreme apex might not originally have been simple, as in Struropus Fagi $\delta$, several of the male Geometrida, \&c. The antennæ may be described as being rather long, and simply pectinated on each side, the pectinations apparently extending nearly to the apex; the thorax is broad, ovate, robust; the anterior wings long and narrow, rounded behind, with rather strong nervures, and hyaline; the posterior abbreviated and small; the abdomen long, robust at the base, and gradually attenuated to the apex; so that its discrepancies from Psyche are sufficiently great to remove it from the same genus: in Psyche the antennæe are short, curved, with short, twisted pectinations, extending evidently to the apex ; the thorax slender ; the abdomen linear, attenuated merely at the apex; the anterior wings broad, subtruncate on the hinder margin, with slender nervures; the posterior elongate and ample; but in both insects all the wings are nearly diaphanous, but mostly so in the Ephemeraformis. I therefore propose to distinguish the latter as a genus by the name

\section{Thy RIDOPTERYX,}

Hübner's genera of the Canephorce being all named from the peculiarities in the wings; and shall conclude by quoting Ochsenheimer's 


\section{$78 \mathrm{Mr}$. Westwood on the Habits of Odynerus Antilope.}

characters of the insect which appears to be synonymous with it; but as I cannot sufficiently decipher his German description, I cannot be positive that the two insects.are identical. Ochsenheimer* says : "Ps. alis angustis hyalinis, corpore atro hirsuto, antennis plumosis."

Upon this last character there exists considerable doubt; and what may be the real colour of the body it is impossible to state, but the wings appear to agree. Of Ochsenheimer's insect (which appears to have been taken in Portugal,) I have not seen a specimen; the English one was found by Mr. Bolton in Yorkshire upwards of fifty years since.

It may be added, that the first notice of this insect was given by Mr. Haworth in his Prodromus Lepidopterorum Britannicorum, p. 35. as a new species, under the name of Tinea fenestrella, associated with the species of the genus Fumea; but at the period of the publication of that work (1802), Psyche fusca, its nearest ally, had not been detected in Britain.

\section{Notice of the Habits of Odynerus Antilope. By J. O. Westwood, F.L.S., \& c.}

[Read June 2, 1834.]

I BEG leave to offer to the Entomological Society a notice of some facts which I have recently observed relative to the habits of $O d y$ nerus Antilope, and which seem to present another exception to the theory of M. St. Fargeau respecting the cconomy of the fossorial Hymenoptera, as well as to throw some light upon the mode of employment of the legs in the construction and provisioning of the nest, both which subjects, it will be remembered, have already upon several occasions occupied the attention of the Society.

It has been long known that the species of Odynerus form their nests in the old mortar of walls or in sand-banks, and that each of these nests is provisioned with about ten or twelve caterpillars, which are arranged in a spiral direction.

Some exceptions as to situation are mentioned in Curtis's Brit. Ent., and in the Mag. Nat. History.

Yesterday morning, 31st May, 1834, in walking at the side of an old brick wall, exposed to the sun, I noticed several specimens of

\footnotetext{
* Vol. iii. p. 176.
} 